\title{
A Rhizobium strain that nodulates and fixes nitrogen in association with alfalfa and soybean plants
}

\author{
W. M. Gao and S. S. Yang \\ Author for correspondence: S. S. Yang. Tel: +8612582244 385. Fax: +8612582332.
}

Department of

Microbiology, Beijing

Agricultural University,

Beijing 100094, Peoples'

Republic of China

\begin{abstract}
A Rhizobium meliloti strain that forms effective nodules on soybean (Glycine max) and alfalfa (Medicago sativa) is described. The strain, 042B, was isolated from root nodules of alfalfa in Xinjiang Autonomous Region of China. Experiments showed that strain 042B was able to nodulate soybean as effectively as Bradyrhizobium japonicum USDA110, a widely used inoculant strain. Under hydroponic conditions, both strains performed similarly in many respects such as time required for the appearance of nodules, total nitrogenase activity, plant top dry weight and total plant nitrogen. In soil pot experiments, total nitrogen, seed weight and seed nitrogen of soybean plants inoculated with strains 042B or USDA110 were much higher than those of the uninoculated control, but there were no differences between plants with strain 042B relative to strain USDA110. However, when strain 042B was the inoculant, the number of nodules was greater, but the nodules were smaller than those of strain USDA110. Results from ELISA showed that nodule occupancy of strain 042B in soybean ranged from $82-90 \%$ and that of strain USDA110 ranged from 78-86\%. Strain 042B can grow in the presence of $5 \%$ (w/v) $\mathrm{NaCl}$, at $42{ }^{\circ} \mathrm{C}$, and at $\mathrm{pH} 10 \cdot 7$. Strain $042 \mathrm{~B}$ was shown to have two large plasmids (molecular sizes $200 \mathrm{~kb}$ and $>1000 \mathrm{~kb}$, respectively). The DNA G +C mol\% of strain 042B was 63.6. The DNA level of homology between strain 042B and type-strain $R$. meliloti USDA1002 was $76 \%$, while DNA homologies of strain 042B were $10 \%$ and $12 \%$ with $R$. fredif USDA205 and B. japonicum USDA6, respectively.
\end{abstract}

Keywords: Rbizobium meliloti, symbiotic nitrogen fixation, broad host range

\section{INTRODUCTION}

Rbizobium strains form nodules only on a restricted number of legume plants, and each legume host is nodulated only by a limited number of microsymbionts (Jordan, 1984). However, the range of host specificity varies greatly among rhizobia. For instance, Rhizobium sp. strain NGR234 nodulates more than 60 different legume genera and the non-legume Parasponia (Denarie et al., 1993). In contrast, Rbizobium meliloti normally has a rather restricted host range, being symbiotic only with species of Medicago, Melilotus and Trigonella (Jordan, 1984). In recent years phylogenetic studies of rhizobia have shown that $R$. meliloti has a very close relationship with the fast-growing soybean rhizobium, R. fredii; 16S rRNA sequences encoded by a 260 bp segment of the DNA from these two species were identical (Jarvis et al., 1992). A close phylogenetic relationship is also supported by serology (Sadowsky et al., 1987). Eardly et al. (1992) reported that strain Or 191 (identified as a relative of R. etli) nodulated both alfalfa and common bean, but in that case nitrogen fixation was poor.

The symbiotic efficiency of R. meliloti and legume host is high, yielding more fixed nitrogen per hectare per year than other rhizobia including soybean rhizobia (Button, 1980). R. meliloti has some specific free-living growth characteristics, such as high salt tolerance (Chen et al., 1987), an optimum growth temperature of $35^{\circ} \mathrm{C}$, with some strains growing at $42^{\circ} \mathrm{C}$ (Jordan, 1984), and a generation time of $2 \mathrm{~h}$ (Vincent, 1982).

Strain 042B was isolated from root nodules of alfalfa in Wulumuqi when a survey of rhizobial resource was made in Xinjiang Autonomous Region of China in 1980 (Chen et al., 1987). We used strain 042B as a donor in conjugation experiments, aimed at constructing salt-tolerant highly effective strains of soybean thizobia. When strain 042B was inoculated on soybean as a control in plant nodulation 
experiments, it was unexpectedly found to nodulate and fix nitrogen with soybean. In this paper, we describe some basic symbiotic, physiological and biochemical characteristics of strain 042B, and its taxonomic relatedness to other rhizobia.

\section{METHODS}

Strains. The bacterial strains used in this study are listed in Table 1.

Media. YMA medium used to cultivate rhizobia was described by Vincent (1970), YM liquid medium is YMA medium without agar. TY liquid medium [0.5\% (w/v) Difco Bacto-Tryptone, $0.3 \%(\mathrm{w} / \mathrm{v})$ Difco Bacto-Yeast Extract and $7 \mathrm{mM} \mathrm{CaCl}_{2}$ ] was used to cultivate rhizobia. The hydrophobic medium was prepared according to Zhou et al. (1979) and was used to cultivate soybean and, after adding $1 \%(\mathrm{w} / \mathrm{v})$ agar to make slopes, for nodulation experiments with alfalfa.

Reisolation of rhizobia. Ten nodules were randomly selected from both alfalfa and soybean plants separately inoculated with strain 042B, immersed in $95 \%(\mathrm{v} / \mathrm{v})$ ethanol for $3 \mathrm{~min}$ and subjected to $0 \cdot 1 \% \mathrm{HgCl}_{2}$ for $5 \mathrm{~min}$. Nodules were rinsed in six changes of sterile water, and homogenized in $2 \mathrm{ml}$ sterile water. Serial 10-fold dilutions of the nodule homogenate were made and $0.1 \mathrm{ml}$ of the dilutions was spread on YMA agar plates containing $0.25 \mathrm{mg}$ bromothymol blue $\mathrm{l}^{-1}$. After surface sterilization, the sterile water used for rinsing the nodules was streaked on YMA agar plates to verify the sterility of the water. All plates were incubated at $28{ }^{\circ} \mathrm{C}$ for $7 \mathrm{~d}$. For each nodule isolate a single colony was selected and restreaked on YMA agar plates and checked for purity. Once pure cultures had been confirmed, each isolate was streaked on YMA agar slopes for nodulation experiment.

Plant nodulation experiments. Nodulation experiments on soybean and alfalfa were carried out using the method described by Vincent (1970) with some modification (Chen et al., 1991). Jingyin No. 1 soybean was grown in jars using a hydroponic

\section{Table 1. Bacterial strains}

\begin{tabular}{|ll|}
\hline Strain & Source* \\
\hline Rhizobium meliloti group A & \\
$042 \mathrm{~B}$ & CCBAU \\
41 & CAAS \\
USDA $1002^{\mathrm{T}}$ & USDA \\
$102 \mathrm{~F} 28$ & USDA \\
CC2013 & B. D. Eardly \\
R. meliloti group B $_{\text {CC169 }}$ & B. D. Eardly \\
Bradyrhizobium japonicum & \\
USDA110 & USDA \\
USDA 6 & USDA \\
Rhizobium fredii & \\
RT19 & This laboratory \\
USDA 205 & USDA \\
CCBAU110 & CCBAU \\
\hline
\end{tabular}

* CAAS, Chinese Academy of Agricultural Sciences; CCBAU, Culture Collection of Beijing Agricultural University; USDA, United States Department of Agriculture. B. D. Eardly, Pennsylvania State University, Berks Campus, Reading, PA, USA. method. The nutrient solution used for the plants contained, per litre of distilled water: $0.03 \mathrm{~g} \mathrm{Ca}\left(\mathrm{NO}_{3}\right)_{2}, 0.46 \mathrm{~g} \mathrm{CaSO}_{4}, 0.06 \mathrm{~g}$ $\mathrm{MgSO}_{4} .7 \mathrm{H}_{2} \mathrm{O}, 0.14 \mathrm{~g} \mathrm{~K}_{2} \mathrm{HPO}_{4}, 0.07 \mathrm{~g} \mathrm{KCl}, 0.07 \mathrm{~g}$ iron citrate and $1 \mathrm{ml}$ of a trace element solution. The trace element solution contained, per litre of distilled water: $2.86 \mathrm{~g} \mathrm{H}_{3} \mathrm{BO}_{3}, 1.8 \mathrm{~g}$ $\mathrm{MnSO}_{4}, 0.8 \mathrm{~g} \mathrm{CuSO}_{4} .5 \mathrm{H}_{2} \mathrm{O}, 0.2 \mathrm{~g} \mathrm{ZnSO}_{4}$ and $0.02 \mathrm{~g} \mathrm{HMoO}_{4}$. Baoding alfalfa was grown in sterilized vermiculite in glass tubes $(200 \times 30 \mathrm{~mm})$ plugged with cotton wool containing the same nutrient solution and nitrogenase activities were determined by acetylene reduction assays (Hardy et al., 1973).

Soil pot experiments. Soil pot experiments were done without sterilization in field soil which had been in soybean production. The experiments included inoculation with strain USDA110, inoculation with strain $042 \mathrm{~B}$ and a control without inoculation, with 12 separate pots for each. All the pots were placed on the ground in the field. Assays of the nitrogenase activity of root nodules, plant top dry weight and total nitrogen were determined at the flowering stage $(50 \mathrm{~d})$, the pod stage $(62 \mathrm{~d})$ and the seed stage $(72 \mathrm{~d})$, with three replicates for each. In the harvest stage $(102 \mathrm{~d})$, seeds were collected from the final three pots for determination of grain yield and total nitrogen.

Agglutination. Antigens were prepared from cells grown in TY liquid medium for $2 \mathrm{~d}$. Somatic cell antigens for injections and for agglutination studies were prepared by heating cell suspensions in a boiling water bath for $30 \mathrm{~min}$. Boiled cell suspensions were used to produce somatic cell antisera by the method of Schmidt et al. (1968). Tube agglutination reactions were performed essentially as described by Vincent (1970).

Nodule occupancy determined by ELISA. ELISA for identification of the soybean rhizobia strain from nodules was performed as described by Fuhrmann \& Wollum (1985).

Growth characteristics. Growth rates at different $\mathrm{pH}$ values were determined as described by Yang \& $\mathrm{Li}$ (1988). Salt tolerance was determined by adding $0.5,1,2,3,4,5$ and $6 \%$ $(\mathrm{w} / \mathrm{v}) \mathrm{NaCl}$ to YMA medium. A growth response in the presence of $\mathrm{NaCl}$ was scored as positive if a strain grew as well as, or better than, it did on control plates containing no additional $\mathrm{NaCl}$. The growth responses of given strains were tested on YMA at different temperatures to determine the maximum temperature at which bacterial growth could take place.

Plasmid analysis. Plasmid analysis was carried out by the method of Eckhardt (1978).

Determinations of DNA G $+\mathbf{C}$ mol\%. DNA was prepared by the method of Johnson (1985). The mean DNA G + C mol\% of each strain was measured using the thermal denaturation method (Marmur \& Doty, 1962) and the equation of De Ley (1970). Escherichia coli K12 was used as the standard.

DNA homology. DNA samples were treated using the method of De Ley et al. (1970) and the levels of homology were determined using the initial renaturation rate method (De Ley $e t$ al., 1970).

\section{RESULTS}

\section{Strain 042B nodulates and fixes nitrogen on both alfalfa and soybean}

The following tests demonstrated that strain 042B was indeed a strain that could nodulate both alfalfa and soybean. When strain 042B reached mid-exponential growth phase in TY liquid medium, a series of dilutions was made with physiological saline containing $0.01 \%$ Tween 20 and then spread on YMA plates to isolate single colonies. Twenty single colonies were randomly picked 
Table 2. Hydroponic nodulation experiment with strains 042B and USDA110 and soybean plants

The values are means of six soybean plants \pm SE. The superscripts a and $b$ indicate statistical similarity and dissimilarity in pairwise comparison.

\begin{tabular}{|c|c|c|c|c|c|c|}
\hline Strain & $\begin{array}{l}\text { Time of } \\
\text { appearance } \\
\text { of nodules } \\
\text { (d) }\end{array}$ & $\begin{array}{l}\text { Nodule } \\
\text { number }\end{array}$ & $\begin{array}{c}\text { Nodule } \\
\text { wt (mg) }\end{array}$ & $\begin{array}{c}\text { Total nitrogenase } \\
\text { activity } \\
\left(\text { nmol } \mathrm{C}_{2} \mathrm{H}_{4} \mathrm{~h}^{-1}\right)\end{array}$ & $\begin{array}{c}\text { Plant top } \\
\text { dry wt (mg) }\end{array}$ & $\begin{array}{c}\text { Total } \\
\text { nitrogen } \\
\text { (mg) }\end{array}$ \\
\hline 042B & 10 & $106^{a} \pm 18$ & $583^{a} \pm 86$ & $22445^{a} \pm 1251$ & $1322^{\mathrm{a}} \pm 126$ & $42 \cdot 15^{a} \pm 7 \cdot 02$ \\
\hline USDA110 & 10 & $63^{b} \pm 15$ & $636^{a} \pm 65$ & $20889^{a} \pm 1330$ & $1362^{\mathrm{a}} \pm 131$ & $34 \cdot 69^{a} \pm 5 \cdot 14$ \\
\hline Uninoculated & - & & - & - & $995^{b} \pm 128$ & $9.89^{\mathrm{b}} \pm 5.04$ \\
\hline
\end{tabular}

Table 3. Soil pot experiment with strains $042 \mathrm{~B}$ and USDA110 analysed in growing stages of soybean plants

The values are means of three replicates \pm SE. Superscripts a and b indicate statistical similarity and dissimilarity in pairwise comparison.

\begin{tabular}{|c|c|c|c|c|c|c|}
\hline $\begin{array}{l}\text { Growing } \\
\text { stage }\end{array}$ & Strain & $\begin{array}{l}\text { Nodule } \\
\text { number }\end{array}$ & $\begin{array}{c}\text { Nodule } \\
\text { wt (mg) }\end{array}$ & $\begin{array}{c}\text { Total nitrogenase } \\
\text { activity } \\
\left(\text { nmol } \mathrm{C}_{2} \mathrm{H}_{4} \mathrm{~h}^{-1}\right)\end{array}$ & $\begin{array}{c}\text { Plant top } \\
\text { dry wt (g) }\end{array}$ & $\begin{array}{c}\text { Total } \\
\text { nitrogen } \\
(\%)\end{array}$ \\
\hline $\begin{array}{l}\text { Flowering } \\
\text { stage }\end{array}$ & $\begin{array}{l}\text { 042B } \\
\text { USDA110 } \\
\text { Uninoculated }\end{array}$ & $\begin{array}{l}266 \pm 38 \\
241 \pm 26 \\
164 \pm 35\end{array}$ & $\begin{array}{l}4827 \pm 525 \\
3883 \pm 491 \\
4490 \pm 562\end{array}$ & $\begin{array}{l}23111^{\mathrm{a}} \pm 1623 \\
28333^{\mathrm{a}} \pm 1425 \\
17778^{\mathrm{b}} \pm 1990\end{array}$ & $\begin{array}{l}33 \cdot 49^{\mathrm{a}} \pm 3 \cdot 02 \\
27 \cdot 62^{\mathrm{b}} \pm 2 \cdot 87 \\
27 \cdot 77^{\mathrm{b}} \pm 3 \cdot 12\end{array}$ & $\begin{array}{l}3 \cdot 65^{\mathrm{a}} \pm 0 \cdot 27 \\
3 \cdot 63^{\mathrm{a}} \pm 0 \cdot 22 \\
3 \cdot 35^{\mathrm{b}} \pm 0.31\end{array}$ \\
\hline $\begin{array}{l}\text { Pod } \\
\text { stage }\end{array}$ & $\begin{array}{l}\text { 042B } \\
\text { USDA110 } \\
\text { Uninoculated }\end{array}$ & $\begin{array}{l}327 \pm 42 \\
238 \pm 38 \\
315 \pm 45\end{array}$ & $\begin{array}{r}7600 \pm 618 \\
6830 \pm 520 \\
10617 \pm 735\end{array}$ & $\begin{array}{r}148161^{\mathrm{a}} \pm 3836 \\
78000^{\mathrm{b}} \pm 3235 \\
79556^{\mathrm{b}} \pm 4250\end{array}$ & $\begin{array}{l}43 \cdot 59^{\mathrm{a}} \pm 2 \cdot 11 \\
37 \cdot 35^{\mathrm{b}} \pm 3 \cdot 59 \\
48 \cdot 26^{\mathrm{a}} \pm 3 \cdot 88\end{array}$ & $\begin{array}{l}3 \cdot 64^{a} \pm 0.31 \\
3 \cdot 41^{a} \pm 0.23 \\
2 \cdot 95^{b} \pm 0.25\end{array}$ \\
\hline $\begin{array}{l}\text { Seed } \\
\text { stage }\end{array}$ & $\begin{array}{l}042 B \\
\text { USDA110 } \\
\text { Uninoculated }\end{array}$ & $\begin{array}{l}296 \pm 41 \\
213 \pm 31 \\
347 \pm 37\end{array}$ & $\begin{array}{l}7187 \pm 535 \\
6573 \pm 581 \\
9677 \pm 620\end{array}$ & $\begin{array}{l}34445^{a} \pm 1940 \\
32333^{a} \pm 2201 \\
32555^{a} \pm 1629\end{array}$ & $\begin{array}{l}51 \cdot 34^{a} \pm 7 \cdot 38 \\
51 \cdot 34^{a} \pm 6 \cdot 08 \\
53 \cdot 80^{a} \pm 6 \cdot 68\end{array}$ & $\begin{array}{l}3 \cdot 72^{\mathrm{a}} \pm 0.22 \\
3 \cdot 56^{\mathrm{a}} \pm 0.28 \\
3 \cdot 10^{\mathrm{b}} \pm 0.32\end{array}$ \\
\hline
\end{tabular}

and inoculated separately onto 20 soybean plants cultured in hydroponic medium and 20 alfalfa plants cultured on the same medium with $1 \%$ agar as slopes. After $10 \mathrm{~d}$, all the soybean and alfalfa plants were nodulated and had acetylene-reducing activity. In contrast, $B$. japonicum USDA110 could only nodulate and fix nitrogen with soybean, and R. meliloti USDA1002 could only do so with alfalfa. Blank controls for both plants were not nodulated.

The isolates obtained from soybean root nodules inoculated with strain $042 \mathrm{~B}$ were fast-growing thizobia. When these isolates were used to inoculate alfalfa and soybean both plants were nodulated and fixed nitrogen. The isolates obtained from alfalfa root nodules inoculated with strain $042 \mathrm{~B}$ had similar nodulation and nitrogen fixation characteristics.

DNA homology was determined between strain $042 \mathrm{~B}$, the re-isolates obtained from soybean root nodule, and the reisolates obtained from alfalfa root nodule. The level of hybridization was $100 \%$ in all combinations.

An antiserum raised against strain $042 \mathrm{~B}$ could agglutinate strain $042 \mathrm{~B}$ and the re-isolates from both soybean and alfalfa root nodules. All cultures yielded the same agglutination value $(1: 1024)$.

These experiments showed that strain 042B could nodulate and fix nitrogen in association with soybean. Therefore, the possibility that our preliminary results were due to contamination by soybean thizobia was ruled out.

Strain 042B and B. japonicum USDA110 were compared for symbiotic efficiency on soybean grown under hydroponic conditions for $38 \mathrm{~d}$ (Table 2). There were no marked differences in time of appearance of nodules, total nitrogenase activities, plant top dry weights and total nitrogen (Table 2). These results indicated that strains 042B and USDA110 were equally effective. The number of nodules produced by strain $042 \mathrm{~B}$ was obviously greater than that of strain USDA110, but total nodule weight was similar in both strains. The strain 042B nodules were smaller (mean weight of single nodule, $5.5 \mathrm{mg}$ ) than strain USDA110 nodules $(10 \cdot 1 \mathrm{mg})$.

To examine nodulation and nitrogen fixation by strain 042B with soybean, unsterilized soil was used in soil pot experiments and strain USDA110 was employed as a standard. The aim of soil pot nodulation experiments was 
Table 4. Soil pot experiment with strains 042B and USDA110 analysed in the harvest stage of soybean plants

The values are means of three replicates \pm SE. Superscripts a and $b$ indicate statistical similarity and dissimilarity in pairwise comparison.

\begin{tabular}{|lccccc|}
\hline Strain & $\begin{array}{c}\text { Pod } \\
\text { number }\end{array}$ & $\begin{array}{c}\text { Seed wt } \\
(\mathbf{g})\end{array}$ & $\begin{array}{c}\text { Weight of } \\
\mathbf{1 0 0} \text { seeds } \\
\mathbf{( g )}\end{array}$ & $\begin{array}{c}\text { Seed } \\
\text { number }\end{array}$ & $\begin{array}{c}\text { Seed } \\
\text { nitrogen } \\
(\%)\end{array}$ \\
\hline 042B & $78^{\mathrm{a}} \pm 8$ & $27 \cdot 57^{\mathrm{a}} \pm 2 \cdot 36$ & $19 \cdot 83^{\mathrm{a}} \pm 0 \cdot 64$ & $151^{\mathrm{a}} \pm 10$ & $6 \cdot 38^{\mathrm{a}} \pm 0 \cdot 26$ \\
USDA110 & $80^{\mathrm{a}} \pm 11$ & $26 \cdot 58^{\mathrm{a}} \pm 3 \cdot 35$ & $19 \cdot 15^{\mathrm{a}} \pm 0 \cdot 55$ & $163^{\mathrm{a}} \pm 25$ & $6 \cdot 53^{\mathrm{a}} \pm 0 \cdot 28$ \\
Uninoculated & $63^{\mathrm{b}} \pm 13$ & $21 \cdot 37^{\mathrm{b}} \pm 2 \cdot 59$ & $18 \cdot 14^{\mathrm{a}} \pm 1 \cdot 20$ & $121^{\mathrm{b}} \pm 19$ & $5 \cdot 85^{\mathrm{b}} \pm 0 \cdot 31$ \\
\hline
\end{tabular}

Table 5. Nodule occupancy (\%) of strains 042B and USDA110 in different growing stages of soybean plants in unsterilized soil

\begin{tabular}{|lcc|}
\hline Growing stage & \multicolumn{2}{c|}{ Strain } \\
\cline { 2 - 3 } & 042B & USDA110 \\
\hline Flowering stage & 85 & 80 \\
Pod stage & 90 & 86 \\
Seed stage & 82 & 78 \\
\hline
\end{tabular}

to estimate the commercial value of strain $042 \mathrm{~B}$ in the field. Table 3 shows that the total nitrogen content of soybean plants inoculated with strain 042 B or USDA110 was somewhat higher during the growing season than that of uninoculated control. In the harvest season, the pod number, seed number, seed weight and total nitrogen of seeds from soybean plants inoculated with $042 \mathrm{~B}$ or USDA110 were higher than those of the uninoculated control, but there were no differences between those with strains 042B and USDA110 (Table 4).

\section{Competition between strain 042B and indigenous rhizobia tested by ELISA}

Twenty soybean root nodules nodulated by indigenous rhizobia were picked out randomly for ELISA, and none reacted with the antisera raised against strains USDA110 and 042B.

To determine nodule occupancy at different times during the growing season, random samples of 80 nodules were taken from soybean plants inoculated with strain $042 \mathrm{~B}$ or USDA110 and tested by ELISA. The results (Table 5), showing greater than $78 \%$ nodule occupancy, indicate that, under unsterilized soil pot conditions strains $042 \mathrm{~B}$ and USDA110 both have strong competitive abilities.

\section{Physiological, biochemical and taxonomic characteristics of strain 042B}

Strain 042B grew faster than strain USDA110; under optimal conditions, the generation time of strains $042 \mathrm{~B}$

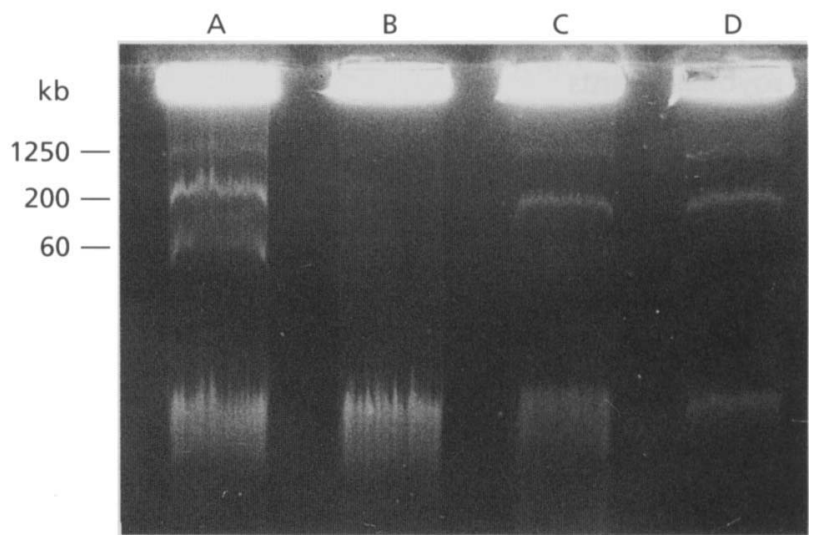

Fig. 1. Agarose gel electrophoresis of plasmid DNA. Lanes: A, Rm41; B, USDA110; C, 042B; D, USDA1002.

and USDA110 were $2.0 \mathrm{~h}$ and $9.6 \mathrm{~h}$, respectively. Strain 042B tolerated higher salt concentration, growing in the presence of $5 \% \mathrm{NaCl}$, while strain USDA110 was inhibited by $0.5 \% \mathrm{NaCl}$. Strain 042B adapted to alkaline conditions $(\mathrm{pH} \mathrm{10.7)}$ and a wider range of temperature $\left(10-42{ }^{\circ} \mathrm{C}\right)$.

In R. meliloti 41 , three plasmids of 60,200 and $1250 \mathrm{~kb}$ have been reported. Of these, the $60 \mathrm{~kb}$ plasmid is an exogenous plasmid RP4 with resistance to kanamycin, tetracycline and ampicillin ( $\mathrm{Yu}$ et al., 1992). We detected two large plasmids in strain 042B (Fig. 1). They appeared to be similar in size to those in R. meliloti USDA1002, which have been estimated to be $200 \mathrm{~kb}$ and $>1000 \mathrm{~kb}$. Strain USDA110 appeared to have no plasmids under our culture conditions.

To confirm the taxonomic position of strain $042 \mathrm{~B}$, DNA $\mathrm{G}+\mathrm{C} \mathrm{mol} \%$ and DNA homology of this strain and related fast- and slow-growing soybean rhizobia were determined. The $\mathrm{G}+\mathrm{C}$ mol\% of 63.6 of strain $042 \mathrm{~B}$ is in the same range as other rhizobia, and those determined for other reference strains were in their published ranges (Jordan, 1984) (Table 6). DNA homology between strain 042B and other alfalfa rhizobia was more than $70 \%$ except for strain CC169, which belongs to division B of $R$. meliloti according to Eardly et al. (1992). DNA homology 
Table 6. DNA homology (\%) between strain 042B and reference strains

\begin{tabular}{|llcc|}
\hline Species & Strain & $\begin{array}{c}\text { G+C } \\
\text { mol\% }\end{array}$ & $\begin{array}{c}\text { Homology } \\
\text { with } \\
\text { 042B (\%) }\end{array}$ \\
\hline R. meliloti group A & 042B & $63 \cdot 6$ & 100 \\
& USDA1002 & $63 \cdot 6$ & 76 \\
& 102F28 & $63 \cdot 2$ & 82 \\
R. meliloti group B B & CC169 & $63 \cdot 3$ & 71 \\
R. fredii & RT19 & $63 \cdot 1$ & 40 \\
& USDA205 & $62 \cdot 8$ & 5 \\
& CCBAU110 & $63 \cdot 1$ & 38 \\
B. japonicum & USDA110 & $64 \cdot 3$ & 14 \\
& USDA6 & $64 \cdot 3$ & 12 \\
\hline
\end{tabular}

between strain 042B and soybean rhizobia was less than $40 \%$ (Table 6).

\section{DISCUSSION}

In this work, we have demonstrated that strain 042B, isolated from alfalfa in Xinjiang Autonomous Region of China, is able to nodulate and fix nitrogen in association with soybean plants. We have shown that this strain is, in other respects, a typical R. meliloti. However, none of the other $R$. meliloti strains that we tested was able to nodulate soybeans. Indeed, such an ability has never previously been reported for this species. The fact that strain 042B could infect and fix nitrogen in soybean plants indicates that the symbiotic capabilities of $R$. meliloti are not necessarily confined to alfalfa and closely related legumes, as was generally believed until now.

Since Xinjiang is in the north-west border area of China, with a typical continental climate, having hot summers and cold winters, the temperature there varies greatly between day and night. It is the driest area in China with high saline alkalinity. The R. meliloti $042 \mathrm{~B}$ growing in this environment has characteristics consistent with such a habitat. Despite the symbiotic and physiological peculiarities of strain 042B, we found that it still belongs to the species R. meliloti based on DNA homology analysis with strain 042B and other rhizobia (Table 6). According to Eardly et al. (1990), alfalfa rhizobia can be divided into two divisions, $\mathrm{A}$ and $\mathrm{B}$. Our results indicate that strain 042B belongs in division $A$.

Jarvis et al. (1992) indicated that the sequence of part of the gene encoding $16 \mathrm{~S} \mathrm{rRNA}$ of $\mathrm{R}$. meliloti was identical to that of fast-growing soybean rhizobia, hence a close phylogenic relationship has been established. In this case, partial sequence of $16 \mathrm{~S}$ rRNA would not allow one to distinguish between R. meliloti and R. fredii. However, DNA homology between them is low. It is possible that they were closely related in the past before evolving into different species.
However, the most interesting question about strain 042B is the nature of its nod genes which may be distinctive. The nod regulatory genes are involved in the detection of plant signals secreted in root exudates, generally flavonoids. Plant flavonoids activate nod structural genes which, in turn, bring about the production of the Nod factors that activate the transcription of plant symbiotic genes. Nod factors secreted by $R$. meliloti are mono- $N$-acylated chitin oligomers that are $\mathrm{O}$-acetylated and $\mathrm{N}$-acylated at the non-reducing end and sulfated at the reducing end. Interestingly, Bradyrbizobium japonicum and R. fredii produce very similar Nod factors which are substituted with a methyl fucose group on the $\mathrm{C} 6$ of the reducing glucosamine residue (Denarie et al., 1993). Hence, strain 042B might secrete a mixture of sulfated and non-sulfated Nod factors which signal back to alfalfa and soybean plants.

Strain $042 B$ has a high symbiotic efficiency on soybeans, displaying early appearance of nodules and a higher nitrogenase activity relative to $B$. japonicum. Its associated plant total nitrogen and seed weight are similar to strain USDA110. In addition, strain 042B can grow under unfavourable conditions, grows faster and utilizes a wider range of carbohydrates than most strains that nodulate soybeans. These advantages are beneficial to the industrial production of rhizobia inoculum. Therefore, strain 042B has a commercial value, but it remains to be studied further in the field.

\section{ACKNOWLEDGEMENTS}

The advice and helpful discussions of J. L. Li and J. P. W. Young are gratefully appreciated. We thank all those who have kindly provided us with strains (Table 1). This work was supported by the National Natural Science Foundation of China.

\section{REFERENCES}

Button, J. C. (1980). New developments in inoculating legumes. In Recent Advances in Biological Nitrogen Fixation, pp. 380-405. Edited by N. S. Subba Rao. London: Arnold Press.

Chen, W. X., Li, G. S., Qi, Y. L., Wang, E. T., Yuan, H. L. \& Li, J. L. (1991). Rbizobium buakuii sp. nov. isolated from the root nodules of Astragalus sinicus. Int J Syst Bacteriol 41, 275-280.

Chen, W. X., Wu, B. H., Luo, C. H., Li, J. L., Shi, Y. H., Huang, L. \& Wu, Z. Y. (1987). The survey and taxonomy of leguminous root nodule bacteria of Xinjiang region. Sci Agric Sin 20, 22-27 (in Chinese).

De Ley, J. (1970). Reexamination of the association between melting point, buoyant density, and chemical base composition of deoxyribonucleic acid. $J$ Bacteriol 101, 738-754.

De Ley, J., Cattoir, H. \& Reynaerts, A. (1970). The quantitative measurement of DNA hybridization from renaturation rates. Eur $J$ Biocbem 12, 133-142.

Denarie, J., Debelle, F., Truchet, G. \& Promé, J.-C. (1993). Rhizobium and legume nodulation: a molecular dialogue. In New Horizons in Nitrogen Fixation, pp. 19-30. Edited by R. Palacios et al. The Netherlands: Kluwer Academic Publishers.

Eardly, B. D., Materon, L. A., Smith, N. H., Johnson, D. A., Rumbaugh, M. D. \& Selander, R. K. (1990). Genetic structure of 
natural populations of the nitrogen-fixing bacterium Rhizobium meliloti. Appl Environ Microbiol 56, 187-194.

Eardly, B. D., Young, J. P. W. \& Selander, R. K. (1992). Phylogenetic position of Rhizobium sp. strain Or 191, a symbiont of both Medicago sativa and Phaseolus vulgaris, based on partial sequences of the 16S rRNA and nifH genes. Appl Environ Microbiol 58, 1809-1815.

Eckhardt, T. (1978). A rapid method for the identification of plasmid DNA in bacteria. Plasmid 1, 584-588.

Fuhrmann, J. \& Wollum, A. G., II (1985). Simplified enzyme-linked immunosorbent assays for routine identification of Rbizobium japonicum antigens. Appl Environ Microbiol 49, 1010-1013.

Hardy, R. W. F., Burns, R. C. \& Holsten, R. D. (1973). Applications of the acetylene-ethylene assay for measurement of nitrogen fixation. Soil Biol Biochem 5, 47-81.

Jarvis, B. D. W., Downer, H. L. \& Young, J. P. W. (1992). Phylogeny of fast-growing soybean-nodulating rhizobia supports synonymy of Sinorbizobium and Rbizobium and assignment to Rbizobium fredii. Int J Syst Bacteriol 42, 93-96.

Johnson, J. L. (1985). Determination of DNA base composition, DNA reassociation and DNA hybridization of bacterial nucleic acid. Methods Microbiol 18, 1-74.

Jordan, D. C. (1984). Family III. Rhizobiaceae Conn 1938, 321 AL . In Bergey's Manual of Systematic Bacteriology, vol. I, pp. 234-242. Edited by N. R. Krieg \& J. G. Holt. Baltimore: Williams \& Wilkins.
Marmur, J. \& Doty, P. (1962). Determination of the base composition of DNA from its thermal denaturation temperature. J Mol Biol 5, 109-118.

Sadowsky, M. J., Bohlool, B. B. \& Keyser, H. H. (1987). Serological relatedness of Rbizobium fredii to other rhizobia and to the bradyrhizobia. Appl Environ Microbiol 5, 1785-1789.

Schmidt, E. L., Bankole, R. O. \& Bohlool, B. B. (1968). Fluorescent antibody approach to the study of rhizobia in soil. J Bacteriol 95, 1987-1992.

Vincent, J. M. (1970). A Manual for the Practical Study of the RootNodule Bacteria. Oxford: Blackwell Scientific Publications.

Vincent, J. M. (1982). Nitrogen Fixation in Legumes. Sydney: Academic Press.

Yang, S. S. \& Li, J. L. (1988). Salt tolerance and nodulation characteristics of fast-growing soybean thizobia. Acta Agric Univ Pek 14, 143-148 (in Chinese).

Yu, Y., Xu, L. M., Fan, H. \& Ge, C. (1992). A study on the plasmid profiles and plasmid deletion of Sinorbizobium fredii strains from different origins. Sci Agric Sin 25, 14-21 (in Chinese).

Zhou, P. J., Den, J. L., Zhang, X. J. \& Wu, S. T. (1979). Nodulation experiments with legume using a hydroponic method. Oil Crops Cbina 2, 60-62 (in Chinese).

Received 5 December 1994; revised 21 March 1995; accepted 28 March 1995. 